\title{
New Strategic Approaches to Gaining from Emerging Advanced Manufacturing Markets
}

\author{
Yuri Simachev* \\ Director and Professor, yusimachev@hse.ru \\ Anna Fedyunina \\ Senior Research Fellow, afedyunina@hse.ru \\ Maksim Yurevich \\ Researcher, mayurevich@hse.ru \\ Mikhail Kuzyk \\ Deputy Director, mkuzyk@hse.ru \\ Nikolai Gorodny \\ Research Intern, na.gorodnyi@hse.ru
}

Center for Industrial Policy Studies, National Research University Higher School of Economics, 11 Pokrovsky Blvd, Moscow, 101000

\begin{abstract}
A dvanced Manufacturing (AM) markets are a major factor of modern global growth which to a large extent determines countries' competitiveness. This article discusses the structure and dynamics of the development of advanced manufacturing markets, as well as the specifics of the policies of the countries strengthening their positions in these markets, based on the analysis of international trade in products using advanced manufacturing technologies.

The study shows that in the last decade there has been a noticeable structural shift in AM: Industry 4.0 is growing faster, and the key growth driver is the biotechnology market. Large innovative economies - USA, France, Japan - are being displaced from AM markets, while new industrialized countries - Korea, Taiwan, and fast-growing China - are becoming leaders. The new AM markets - Industry $4.0-$ are characterized by a high concentration of knowledge in universities combined with a high activity of start-ups, while

the relatively traditional AM markets - Industry $3.0-$ show a higher concentration of production. The position of countries in Industry 4.0 markets is significantly related to the monopoly of new knowledge and the opportunities for its rapid commercialization in start-ups, while in Industry 3.0 markets the processes of leading firms' specialization and use of scale are already more significant, and the research environment is becoming more competitive.

Strengthening and/or optimizing the positions on AM markets becomes the most important challenge for modern industrial policy. On the one hand, the choice of target markets determines significant alternatives in industrial policy (e.g., betting on the creation of new knowledge or on the spread of advanced technology), on the other hand, the sensitivity of progress to the complementarity of changes forms the demand for a comprehensive industrial policy, combining elements of science and technology, innovation, investment, and human capital development policies.
\end{abstract}

Keywords: advanced manufacturing; strategies; innovation; new technologies; biotechnology; Industry 4.0; international trade; industrial policy
Citation: Simachev Y., Fedyunina A., Yurevich M., Kuzyk M., Gorodny N. (2021) New Strategic Approaches to Gaining from Emerging Advanced Manufacturing Markets. Foresight and STI Governance, 15(3), 6-21. DOI: 10.17323/2500-2597.2021.3.6.21

\footnotetext{
* Yury Simachev is also Director for Economic Policy at the HSE.
} 


\section{Introduction}

Advanced technologies are changing the global manufacturing landscape. Many developing countries are losing their main advantage in the form of cheap labor under the pressure of automation [World Bank, 2016]. Developed economies are becoming more independent due to the reduced costs of certain processes [Hallward-Driemeier, Nayyar, 2018; UNIDO, 2020; Rodrik, 2018].

It is widely believed that advanced manufacturing (AM) is concentrated in just a few countries, while for others, entry onto relevant markets is closed or limited [Kim, Qureshi, 2020]. No tools are currently available to assess individual economies' competitiveness and positions on AM markets. Patent data is usually used to analyze the dissemination of advanced manufacturing and fourth industrial revolution technologies (AMTs and Industry 4.0, respectively) [Kim, Bae, 2017; Fujii, Managi, 2018; Ardito et al., 2018]. Such studies reflect the rate of new technology development, but the scale of their practical application is measured only to a limited extent [Castelo-Branco et al., 2019]. Practically no international comparisons have been made [Horváth, Szabó, 2019; Fulton, Hon, 2010]. Readiness for advanced manufacturing is often assessed via innovation development indices [Naudé et al., 2019; Simachev et al., 2020]. There is no single, generally accepted definition of AM, though its key characteristics include the ability to customize and scale production in the process of improving technologies. Based on the definitions proposed in [STPI, 2010; Shipp et al., 2012], AM comprises traditional and high-tech industries which upgrade existing and create new materials, products, and processes. This is achieved by integrating technology with a highly productive workforce and innovative business models. The goal of this paper is to identify the structural features of AM markets and assess their importance for specific national economies through the prism of international trade in high-technology products.

\section{Methodology}

Approaches to assessing international trade in AM products command researchers' and policymakers' interest, but various countries pursue very dif- ferent goals in this area. In China such analysis is primarily conducted to design national industrial strategy and covers products manufactured using not only AMTs but also other technologies. In the United States, this process is not directly linked to accomplishing strategic goals but is applied only for the statistical monitoring of international trade [Ferrantino et al., 2010].

Since AMTs are used in traditional and new industries alike, it is rather difficult to draft a precise list of them. A generally accepted view is that the AM definition should be dynamic and its technological "frontier" should be flexible and mobile. ${ }^{1}$ This assumption is in line with the approach of the US Census Bureau which has developed the first AMT product classification to measure international trade in 1989. It has been regularly revised to reflect the changes in the Harmonized System (HS) ${ }^{2}$ codes on the basis of expert evaluation.

The methodology for defining AM markets applied in this study is based on combining the US Census Bureau approach ${ }^{3}$ with the one presented in [Foster-McGregor et al., 2019]; the latter work identified four types of Industry 4.0 technologies: bio-, CAD/CAM, additive technologies, and robotics. We used COMTRADE data ${ }^{4}$ for 2002-2018 (sixdigit codes-based product classifications HS 2002 and HS 2017). The HS classification was revised in 2002, 2007, 2012, and 2017. New codes were added to take into account the growing product range. However, the updated HS version does not allow for making retrospective assessments, i.e., it does not allow one to analyze data over long periods of time. Therefore, the HS 2017 classification was used to describe the 2017-2018 markets, ${ }^{5}$ while comparing it with the HS 2002 version allowed the authors to reveal long-term shifts in international trade. Eleven global AMT product markets were analyzed and divided into three groups ${ }^{6}$ (Table 1, Figure 1).

\section{Structural Features of Global AM Markets}

In 2018 , AM markets amounted to $21.4 \%$ of total global exports, which is slightly higher than in

\footnotetext{
https://www.nist.gov/system/files/documents/2017/05/09/advanced-manuf-papers.pdf, accessed on 27.12.2020.

https://www. trade.gov/harmonised-system-hs-codes, accessed on 19.11.2020.

3 https://www.census.gov/manufacturing/m3, accessed on 04.12.2020.

https://comtrade.un.org/, accessed on 08.12.2020.

Analyzing the value of the world's AM markets on the basis of the HS 2017 classification allows one to refine the estimates obtained using the HS 2002 nomenclature, including the overall AM market size: for HS 2002 codes, the market was 5.965 trillion USD, and for HS 20178.56 trillion USD in 2018 (a $43.5 \%$ growth). However, this more precise estimate did not reveal significant shifts in the AM market structure. E.g., the share of ICT in the aggregate AM market according to the HS 2002 nomenclature is $30.1 \%$, and according to HS 2017 it is $34.1 \%$, life sciences $20.7 \%$ and $14.8 \%$, aerospace industry $12.4 \%$ and $8.5 \%$. The most significant discrepancy is in electronics ( $11.2 \%$ vs $24.2 \%$ ). The structural shifts in countries' positions are less significant: in 2018 China's share amounted to $15.9 \%$ of the world's total exports of AM products according to HS 2002, and 19.4\% according to HS 2017 . Germany's share was $11.3 \%$ and $8.8 \%$, the US's $9.5 \%$ and $8.8 \%$, respectively.

6 The product groups under consideration can belong to several markets at the same time and the US Census Bureau's approach does take this into account. E.g., according to the US Census Bureau classification, optical media for sound recording should be attributed to three AM markets: optoelectronics, electronics, and ICT. According to the same nomenclature, electrodiagnostic equipment simultaneously belongs on the life sciences and electronics markets. To avoid a double count of the same commodities on different AM markets when analyzing the aggregate global market, the items were assigned to a single market by expert evaluation.
} 
the early 2000 s (18.2\%). The share of Industry 4.0 products in total exports has marginally increased, from $5.1 \%$ to $5.8 \%$ (Figure 2). The growth rate of AM products' share in global trade over the past two decades was lower than expected. As will be shown below, significant structural changes took place on the markets, which turned out to be vulnerable to global economic crisis. The double-digit growth rates of almost all segments observed in 2002-2007 in the post-crisis period were replaced by negative or weakly positive ones (Table 2). The slower growth is largely due to increased tension in international economic relations, the aggravation of "trade wars", and the efforts to strengthen national technological security.

In 2013-2018, the Industry 4.0 segment rapidly grew, while the growth of Industry 3.0 product markets slowed down due to saturation. Biotechnology is the most rapidly growing area (these markets' share grew from $1.8 \%$ in 2002 to $6.6 \%$ in 2018). This growth that is unrelated to the state of the global economy probably can be explained by the specific features of the dominant products, i.e., medical supplies of biological origin. The reduced growth of the nuclear technology market is largely due to the accident in Japan in 2011 and the transition to alternative energy sources primarily in the leading countries [Gasparatos, 2017]. The Industry 3.0 segment accounts for slightly less than half of the total AM market (Figure 3). The small shares of armaments and especially nuclear energy are due to the domestic consumption of relevant products in the producer countries and, consequently, their lower involvement in international trade.

\section{Countries' Positions on AM Markets}

At the end of 2018, China was the clear leader on the aggregate AM product market, mainly due to ICT services (67\% of relevant product exports). Germany and the US were slightly behind, with more diversified markets. In Germany, the life sciences segment accounts for $24 \%$, ICT for $17 \%$, and electronics for $14 \%$. In the United States, ICT services amount to $29 \%$, life sciences to $21 \%$, and electronics to $20 \%$. Next comes Hong Kong, which specializes in ICT services and electronics (Figure 4).

Leaders on the aggregate global AM market also hold leading positions in most of its segments. China is among the top five countries on seven markets, the US and Germany on ten (the only "lost" market for both these countries is electronics, which is the second largest). Many smaller economies including Ireland, Belgium, Spain, Singapore, and Vietnam dominate certain markets; notably, their positions are not directly related to their development level or their scale of economic activities (Table 3).

Russia's share on global AM markets does not exceed $0.6 \%$; the same is true for the aggregate hi-tech product market (no more than $0.5 \%$ ), with the exception of nuclear technology (16.7\% of the global market) and armaments (1.2\%). The country's positions are especially strong in the electronics, optoelectronics, ICT services, and life sciences segments. Biotechnology products have the smallest share. In 2002-2018 the technological "portfolio" in the biotechnology and life sciences segment grew (the gap with Germany, the US, Korea, and China has narrowed). Thus, Russia's relatively low "involvement" on global AM markets is due not to a narrow product specialization but rather to the low competitiveness of its products. China has a comparative advantage (according to the Balassa Index ${ }^{7}$ ) in antioxidants (life sciences) and ICT products (computers, video recorders, monitors, and mobile phones). Germany dominates the flexible manufacturing systems market (including hydraulic and pneumatic devices). Russia's positions are strongest in the production of jet engines (aerospace), nuclear reactors and components, and heat dissipating elements (nuclear technology). China's leadership is due to the general redistribution of the balance of power on the global AMT product markets. India and Vietnam are getting closer to the leader. Mexico has been making steady progress since 2010 , while the US and a number of European countries have reached a "plateau" (Table 4).

Changing the balance of power on the AM markets has led to traditional innovation leaders (the US, France, and Japan) being pushed aside by China, Korea, Taiwan, Singapore, the Philippines, India, Mexico, and Vietnam. This trend did not affect Germany, which is still advancing in the markets under consideration. The decline in other leading countries' market shares is due not only to the pressure from new players, but also to their switching to more promising areas such as Industry 4.0 (e.g., Germany, the UK, and Ireland). Ireland's success in the aerospace sector is based on the establishment of a global aircraft leasing hub [OsborneKinch, 2017] and in biotechnology - on attracting investment and building advanced production infrastructure. However, the country's position in life sciences has weakened due to the growing competition from China and India. The UK's falling into the "outsiders" group on all five markets was also caused by the strengthening of the Asian countries.

The definition of the Revealed Comparative Advantage Index (RCA) in [Balassa, 1965] was used in this study. The index is calculated for each AM market as the ratio of its share in the country's total AM product exports to the share in total global exports of AM products. If RCA $>1$, the country is generally believed to have a revealed comparative advantage in the export of relevant products. 


\section{Figure 1. AMT Product Markets and their Share} on the Aggregate AM Market (\%)

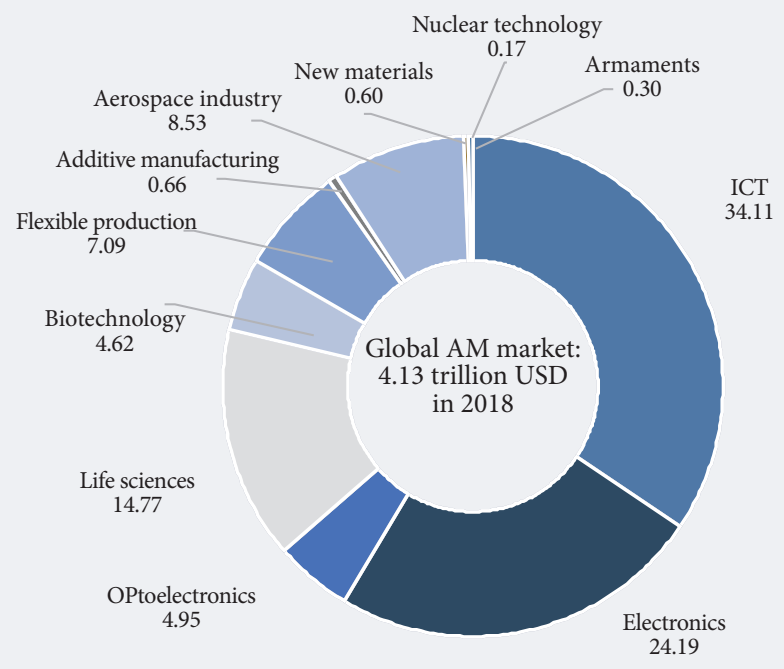

Sources: authors' calculations based on US Census Bureau data for 2020, [Schwab, 2014], COMTRADE data for 2018, and HS 2017 classification.
The growing share on the aerospace market is due to the increased supply of aircraft components, primarily engines (Figure 5).

The changes in the global AM markets' "design" among other things have been caused by the implementation of industrial policies aimed at increasing competitiveness and accelerating growth through structural reforms. However, countries' priorities and implementation methods vary significantly. Industry 4.0 radically changes the understanding of industrial policy vector and stakeholders [Reischauer, 2018]. Germany, China, and the US are striving to maintain leadership by increasing value added in the manufacturing industry. France and Japan localize production, increase its sustainability, and reduce the negative effects of high labor costs. France aims to modernize its manufacturing basis and retain AM leadership, provided it can contain labor costs growth and related social factors [Blanchet et al., 2016]. Russia's industrial policy is mostly vertical in nature, providing selective support and "appointing champions" - industries

\section{Table 1. Classification of AM Markets}

\begin{tabular}{|l|l|l|c|}
\hline \multicolumn{1}{|c|}{ Group } & $\begin{array}{l}\text { Number of } \\
\text { markets }\end{array}$ & \multicolumn{1}{|c|}{ Composition } & $\begin{array}{c}\text { Share in aggregate } \\
\text { AM market (\%) }\end{array}$ \\
\hline Industry 3.0 & 3 & Electronics, optoelectronics, ICT & 63.2 \\
\hline Industry 4.0 & 4 & $\begin{array}{l}\text { Additive manufacturing, biotechnology, life sciences, flexible production } \\
\text { (including robotics) }\end{array}$ & 27.2 \\
\hline Other & 4 & New materials, aerospace, nuclear technologies, armaments & 9.6 \\
\hline
\end{tabular}

* Products not directly related to Industry 3.0 and 4.0. COMTRADE data includes only public information on international trade in armaments. Thus the above estimates do not reflect this market's actual size. However, using this approach makes sense for two reasons. Other available data allows to estimate the overall arms market size without breaking it down into product types (e.g. the SIPRI Arms Transfers Database project). For us, it's important to consider structural shifts not only between markets but also within them, at the level of specific product groups. In line with the adopted approach, the arms market comprises not only armaments and their parts, but also prismatic infrared binoculars, optical telescopes, periscopes, navigation logbooks, and depth sounding equipment..

Source: authors.

\section{Table 2. Average Annual Growth of AM Product Markets and Global Product Exports} (in current prices), by Period (\%)

\begin{tabular}{|c|c|c|c|c|c|}
\hline \multirow{2}{*}{ Group } & \multirow{2}{*}{ AMT product market } & \multirow{2}{*}{$\begin{array}{c}\text { Total for } 2002- \\
2018\end{array}$} & \multicolumn{3}{|c|}{ Out of that during: } \\
\hline & & & $2002-2007$ & 2008-2013 & 2014-2018 \\
\hline \multirow{3}{*}{ Industry 3.0} & Electronics & 5.2 & 28.2 & -11.0 & 1.4 \\
\hline & Optoelectronics & 5.5 & 10.1 & 8.3 & -3.3 \\
\hline & ICT & 5.0 & 14.9 & 1.8 & -1.2 \\
\hline \multirow{4}{*}{ Industry 4.0} & Additive manufacturing & 5.7 & 14.0 & 1.6 & 0.8 \\
\hline & Biotechnology & 15.3 & 24.4 & 12.9 & 8.3 \\
\hline & Life sciences & 6.9 & 16.5 & 2.4 & 1.6 \\
\hline & Flexible production & 8.5 & 20.1 & -0.9 & 8.1 \\
\hline \multirow{4}{*}{$\begin{array}{l}\text { Other AM } \\
\text { markets }\end{array}$} & New materials & 8.7 & 20.9 & -2.7 & 8.5 \\
\hline & Aerospace & 4.9 & 10.5 & -0.2 & 2.6 \\
\hline & Nuclear technology & 1.3 & 16.3 & -4.5 & -5.9 \\
\hline & Armaments & 6.7 & 9.8 & 5.6 & 4.2 \\
\hline \multirow{2}{*}{ For reference } & All AM markets & 6.1 & 17.0 & 0.2 & 1.4 \\
\hline & Global product exports & 7.1 & 16.6 & 3.2 & 0.7 \\
\hline
\end{tabular}




\section{Figure 2. Shares of AM and Industry 4.0 Markets} in Total Product Exports (\%)

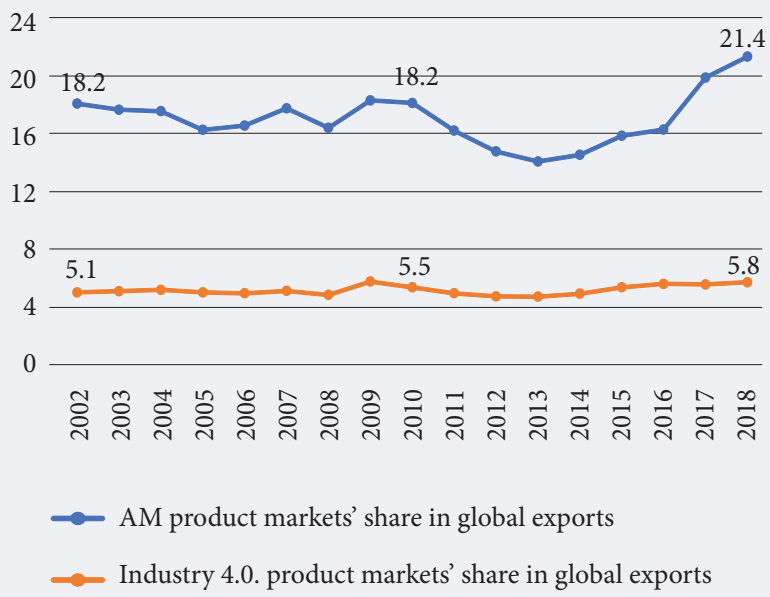

Sources: authors' calculations based on COMTRADE data and HS 2002 classification.

and individual companies [Simachev et al., 2020; HSE, 2018]. As a consequence, public support is typically provided to large players in traditional sectors. Policy evaluation and adjustment as well as abandoning ineffective projects remain rare and limited. Policy areas, tools, and initiatives aimed at compensating for unfavorable changes or encouraging catching-up development of industries and companies dominate, while attempts to adopt development models which would allow for taking the lead remain rare and fragmentary [Simachev et

\section{Figure 3. Global AM market Structure (\%)}

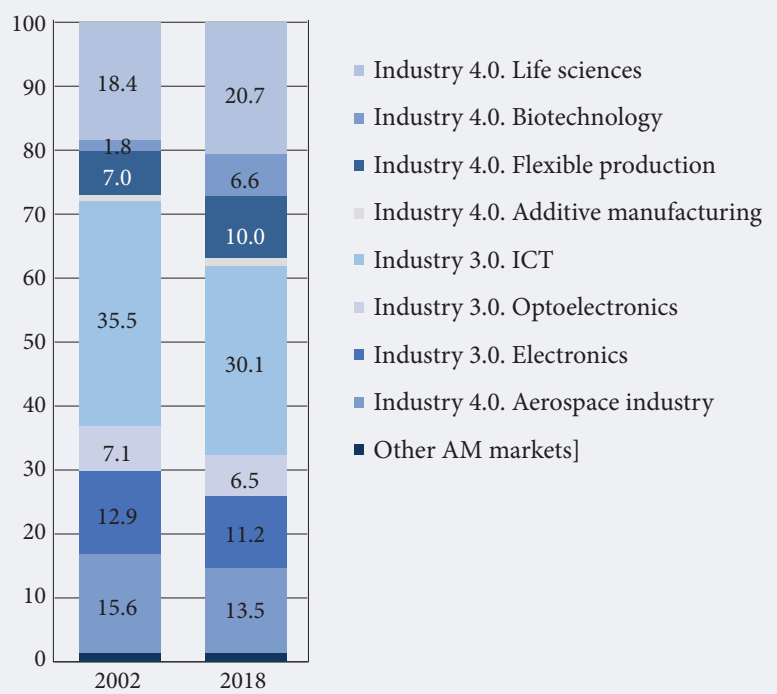

Sources: authors' calculations based on COMTRADE data and HS 2002 classification. al., 2018]. Countries' positions on export and import markets are generally similar. The five largest importers are the US (15.9\% of the total in 2018), China (15.6\%), Hong Kong (8.3\%), Germany $(6.4 \%)$, and Japan $(4.0 \%)$ (Figure 6).

In 2002-2018 China gradually pushed the US out in the imports of AM products. Russia and Vietnam stand out among other countries which have noticeably increased their share on the aggregate import market. The US currently leads in nine out of eleven AM import markets; the exceptions are electronics and flexible production systems where China dominates and the US comes in second. China is not among the top five biotechnology and armament importers. Germany leads in eight segments. Russia is not one of the top five importers in any segment, but still has larger import shares than export ones (except for nuclear technologies and armaments). In per employee terms, the country's weight on the export and import AMT product markets is almost the same. Globally, AMT product export unit costs explain up to $93.5 \%$ of the changes in the same indicator for imports (Figure 6). This means that countries actively manufacturing AMT products for foreign markets are also major consumers of such goods, using them both as intermediate products for export (including in the scope of global value chains) and as finished end products (taking into account the relative specialization in specific AM markets). The group of countries whose per employee AMT product exports and imports exceed 10,000 USD mainly comprises developed economies or those approaching

\section{Figure 4. Selected Countries' Shares in Total} Exports of AM Products: 2018 (\%)

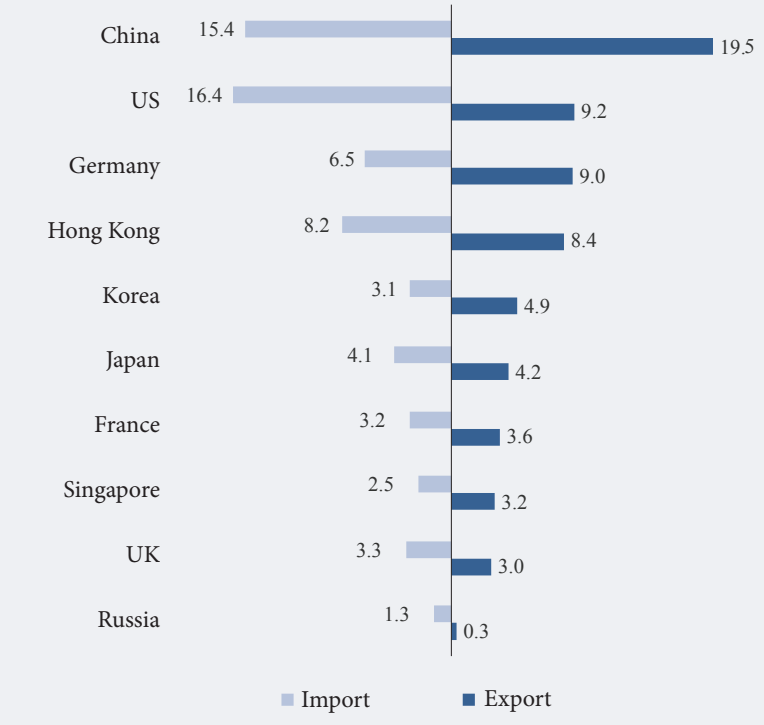

Sources: authors' calculations based on COMTRADE data and HS 2017 classification. 


\begin{tabular}{|c|c|c|c|c|c|c|c|}
\hline Group & AM market & 1st place & 2nd place & 3rd place & 4th place & 5 th place & $\begin{array}{l}\text { For reference: } \\
\text { Russia's share }\end{array}$ \\
\hline \multirow{3}{*}{ Industry 3.0} & Electronics & $\begin{array}{c}\text { Hong Kong } \\
(15.9)\end{array}$ & $\begin{array}{l}\text { China } \\
(14.3)\end{array}$ & $\begin{array}{l}\text { Korea } \\
(12.4) \\
\end{array}$ & $\begin{array}{c}\text { Taiwan } \\
(10.8)\end{array}$ & $\begin{array}{c}\text { Singapore } \\
(9.5)\end{array}$ & 0.1 \\
\hline & Optoelectronics & $\begin{array}{l}\text { China } \\
(24.1)\end{array}$ & $\begin{array}{c}\text { Germany } \\
(10.7)\end{array}$ & $\begin{array}{c}\text { US } \\
(8.4) \\
\end{array}$ & $\begin{array}{c}\text { Japan } \\
(5.5) \\
\end{array}$ & $\begin{array}{c}\text { Korea } \\
(5)\end{array}$ & 0.6 \\
\hline & ICT & $\begin{array}{l}\text { China } \\
(37.8)\end{array}$ & $\begin{array}{c}\text { Hong Kong } \\
(11.2)\end{array}$ & $\begin{array}{c}\text { US } \\
(7.5)\end{array}$ & $\begin{array}{l}\text { Vietnam } \\
\quad(4.9)\end{array}$ & $\underset{(4.4)}{\operatorname{Germany}}$ & 0.2 \\
\hline \multirow{4}{*}{ Industry 4.0} & Additive manufacturing & $\begin{array}{c}\text { Germany } \\
(23.4)\end{array}$ & $\begin{array}{l}\text { China } \\
(15.9)\end{array}$ & Japan (9.6) & $\begin{array}{l}\text { Italy } \\
(9)\end{array}$ & $\begin{array}{l}\text { US } \\
(6.1) \\
\end{array}$ & 0.1 \\
\hline & Biotechnology & $\begin{array}{c}\text { Switzerland } \\
(16.5)\end{array}$ & $\begin{array}{l}\text { Ireland } \\
(16.4)\end{array}$ & $\begin{array}{c}\text { Germany } \\
(15.8)\end{array}$ & $\begin{array}{l}\text { US } \\
(13)\end{array}$ & $\begin{array}{l}\text { Belgium } \\
(9.4)\end{array}$ & 0.1 \\
\hline & Life sciences & $\begin{array}{c}\text { Germany } \\
(14.5)\end{array}$ & $\begin{array}{c}\text { US } \\
(12.3)\end{array}$ & $\begin{array}{c}\text { Switzerland } \\
(10.6)\end{array}$ & $\begin{array}{l}\text { Ireland } \\
(8.2)\end{array}$ & $\begin{array}{l}\text { Belgium } \\
\quad(6.5)\end{array}$ & 0.1 \\
\hline & Flexible production & Japan (15.5) & $\begin{array}{c}\text { Germany } \\
(15.3)\end{array}$ & $\begin{array}{c}\text { US } \\
(12.1)\end{array}$ & $\begin{array}{l}\text { China } \\
(8.8)\end{array}$ & $\begin{array}{c}\text { Korea } \\
(6.5)\end{array}$ & 0.3 \\
\hline \multirow{4}{*}{$\begin{array}{l}\text { Other AM } \\
\text { markets }\end{array}$} & New materials & $\begin{array}{l}\text { China } \\
(22.4)\end{array}$ & $\begin{array}{l}\text { Japan } \\
(18.2) \\
\end{array}$ & $\begin{array}{c}\text { US } \\
(12.3) \\
\end{array}$ & $\begin{array}{c}\text { Germany } \\
(6.8)\end{array}$ & $\begin{array}{c}\text { Korea } \\
(6.4)\end{array}$ & 0.6 \\
\hline & Aerospace & France (19.6) & $\begin{array}{c}\text { Germany } \\
(16.6)\end{array}$ & UK (13) & $\begin{array}{l}\text { US } \\
(6)\end{array}$ & $\begin{array}{c}\text { Singapore } \\
(5.9)\end{array}$ & 1.2 \\
\hline & Nuclear technology & Russia (16.7) & $\begin{array}{c}\text { Germany } \\
(16.2)\end{array}$ & France (12.2) & $\begin{array}{c}\mathrm{US} \\
(11.7)\end{array}$ & $\begin{array}{l}\text { Netherlands } \\
\text { (11) }\end{array}$ & - \\
\hline & Armaments & $\begin{array}{c}\text { US } \\
(43.4)\end{array}$ & $\begin{array}{l}\text { China } \\
(5.1)\end{array}$ & $\begin{array}{l}\text { Korea } \\
(5.1)\end{array}$ & $\underset{(4.4)}{\text { Germany }}$ & $\begin{array}{l}\text { Spain } \\
(3.5)\end{array}$ & 1.2 \\
\hline
\end{tabular}

this level: the EU member states, the US, Canada, Japan, the UAE, Malaysia, South Korea, and Israel.

\section{Factors Affecting Countries' Leadership on AM Markets}

Countries' positions in AMT product trade correspond to their global leading university rankings [Tuesta et al., 2019; Marginson, 2007; Marginson, van der Wende, 2007]. A correlation between the number of such universities and AMT product exports was established in life sciences, biotechnology, ICT, electronics and optoelectronics, additive technologies, flexible production, and aerospace segments.

A group of leading countries stands out, with at least five universities included on the top 500 list (except for Israel which has four), while their AMT exports amount to at least $2 \%$ of GDP. For the majority of them, centuries-old academic traditions paved the way to leadership in educational rankings (the UK, Germany, China, France, Italy, Belgium, Switzerland, and the Netherlands). A relatively recent addition is South Korea. Another cohort is "promising AMT exporters": Australia, Russia, India, Argentina, Brazil, and New Zealand. The ratio of relevant product exports to GDP does not exceed $2 \%$ there, and these countries also have at least five universities among the world's top 500 . The distribution of knowledge production centers (universities included in global subject-specific
Table 4. Selected Countries' Shares in Global Imports of Advanced AM Products (\%)*

\begin{tabular}{|c|c|c|c|c|c|}
\hline Country & 2002 & 2006 & 2010 & 2014 & 2018 \\
\hline China & 6.2 & 12.4 & 15.5 & 16.9 & 15.9 \\
\hline US & 17.4 & 14.5 & 10.4 & 10.5 & 9.5 \\
\hline Germany & 9.6 & 10.5 & 9.5 & 10.6 & 11.3 \\
\hline Japan & 8.9 & 7.4 & 6.7 & 4.7 & 4.6 \\
\hline Hong Kong & 4.4 & 5.4 & 6.3 & 5.0 & 4.8 \\
\hline Brazil & 0.4 & 0.3 & 0.3 & 0.3 & 0.3 \\
\hline Russia & 0.4 & 0.2 & 0.2 & 0.4 & 0.3 \\
\hline India & $\mathrm{n} / \mathrm{a}$ & 0.2 & 0.4 & 0.9 & 0.9 \\
\hline South Africa & 0.1 & 0.1 & 0.1 & 0.1 & 0.1 \\
\hline Korea & 3.1 & 3.1 & 3.6 & 2.5 & 3.1 \\
\hline Mexico & 2.9 & 1.7 & 1.5 & 2.2 & 2.8 \\
\hline Taiwan & $\mathrm{n} / \mathrm{a}$ & 2.7 & 3.9 & 2.4 & 2.4 \\
\hline Philippines & $\mathrm{n} / \mathrm{a}$ & $\mathrm{n} / \mathrm{a}$ & 0.4 & 0.6 & 0.6 \\
\hline Turkey & 0.1 & 0.1 & 0.1 & 0.1 & 0.2 \\
\hline Vietnam & $\mathrm{n} / \mathrm{a}$ & 0.1 & 0.1 & 0.5 & 0.8 \\
\hline Malaysia & 3.1 & 2.7 & 2.6 & 1.8 & 2.0 \\
\hline Nigeria & $\mathrm{n} / \mathrm{a}$ & 0.0 & 0.0 & 0.0 & 0.0 \\
\hline Norway & 0.3 & 0.3 & 0.3 & 0.3 & 0.2 \\
\hline Canada & 2.0 & 1.6 & 1.3 & 1.4 & 1.4 \\
\hline Egypt & $\mathrm{n} / \mathrm{a}$ & $\mathrm{n} / \mathrm{a}$ & 0.0 & 0.0 & 0.0 \\
\hline \multicolumn{6}{|c|}{$\begin{array}{l}\text { *To analyse the changes in the aggregate AM market situation, } \\
\text { we selected countries at different stages of economic development } \\
\text { according to the World Bank classification, including: developed, newly } \\
\text { industrialised, and emerging ones, and the BRICS group. }\end{array}$} \\
\hline \multicolumn{6}{|c|}{$\begin{array}{l}\text { Sources: authors' calculations based on COMTRADE data and HS } 2002 \\
\text { classification. }\end{array}$} \\
\hline
\end{tabular}


rankings) in AM markets is consistent with the geography of innovative start-up creation. According to Crunchbase, nearly $40 \%$ of AMT companies are established in the US, ${ }^{8}$ followed by the UK $(5.5 \%)$, China (5.2\%), Germany (4.1\%), and Canada (3.6\%).

In the Czech Republic, Slovakia, Romania, Hungary, Ukraine, Hong Kong, and Taiwan, most of such companies specialize in electronics. Biotechnological firms are mainly located in the US, Canada, Australia, Israel, the UK, Ireland, and Switzerland. Russia and India have numerous robotics start-ups, but the level of job robotization is negligible. Startup distribution by industry in individual countries is close to the world average. With the exceptions of Belgium and Switzerland, the ICT sector is dominated by developing countries (Malaysia, Indonesia, Brazil, South Africa, the UAE); the share of start-ups there is more than double the global average. The main features of AM markets are presented in Table 5.

The Industry 4.0 and electronics markets are extremely competitive and have a high concentration of knowledge production (as illustrated by the number of leading universities). The emerging nature of Industry 4.0 markets is indicated by their concentration in just a few countries due to the unique nature and limited availability of knowledge upon which the relevant technologies are based. The associated Industry 3.0 electronics market is gaining new momentum. These markets have not yet reached the scale which would lead to emergence of global manufacturing hubs (such as in optoelectronics and ICT). Compared to the Industry 4.0 markets, aerospace, nuclear technology, armaments, optoelectronics, and ICT demonstrate higher production activity and stronger competition in knowledge creation, which allows one to classify them as mature. These sectors' development prospects largely depend on the level of production globalization.

\section{Case Studies of Countries - New AM Market Leaders}

Over the past few decades a number of countries have significantly improved their positions on AM markets, so their success strategies are worthy of analysis. We will consider the examples of Vietnam, Ireland, Turkey, and South Korea.

In 20 years' time, Vietnam has managed to become one of the world leaders in the production of electronics by attracting foreign direct investment and supporting foreign companies. Ireland and Turkey have shown strong performance on the biotechnology market. In 10 years, Ireland has quadrupled its global market share, while Turkey shows the fastest growth of exports. In both countries, entry onto the markets under consideration was actively supported by the government, but in different ways. In Turkey this process was mainly driven by small and medium-sized businesses and in Ireland by global pharmaceutical corporations. South Korea is a model example of building up innovation potential and increasing the number of universities included in the top 100 rankings. The close integration of science and the real sector helped the country achieve a leading position in terms of the share of researchers leaving the real sector to work in academia.

\section{Vietnam: the production of electronics}

Having successfully integrated into global value chains, since the 2000s Vietnam has consolidated its leading position in electronics. In terms of production costs, the country has risen from $47^{\text {th }}$ place among the world's exporters in 2001 to $12^{\text {th }}$ in 2019. Currently, the share of electronics amounts to about $36 \%$ of gross national exports and $30 \%$ of total imports.

Consumer electronics make up the bulk of the exports: mobile phones, televisions, cameras $(41 \%)$, electrical appliances (18.2\%), and electronic integrated circuits $(11.9 \%)$. Imports mainly consist of semi-finished products such as micro-components (40\%) and semiconductor devices (6\%). Most of the products are exported to China (19.3\%), the US (18.2\%), South Korea (9.1\%), Hong Kong (4.9\%), and Japan $(4.9 \%)$, and imported from China (33\%), South Korea (31\%), Japan (8\%), and the US (6.5\%).

Vietnam is the only leading producer of electronics who is becoming increasingly dependent upon foreign components. The share of foreign value added in electronics exports which stood at 36\% in 2005 grew to $44 \%$ by 2015 . To compare, in China during the same time it decreased from $26 \%$ to $17 \%$, in Malaysia from $45 \%$ to $37 \%$, and in the Philippines from $27 \%$ to $22 \%$. Multinational companies dominate the sector: although their number currently does not exceed $30 \%$ of all players, they account for about $90 \%$ of exports and control $80 \%$ of the domestic market. Among the largest investors are Samsung, LG, Intel, Canon, Compal Electronics, Jabil Circuit, Microsoft, Nokia, and Foxconn [Ngoc, Binh, 2019].

The accomplishments have been largely made possible by reforms in trade and industrial policies aimed at integrating the country into global value chains. Reduced tariffs to meet the requirements of the ASEAN Free Trade Area (AFTA) and the bilat-

\footnotetext{
Crunchbase is an online start-up information platform maintained by TechCrunch, a US technology publication (https://www.crunchbase.com). These results may be partly due to base bias: Crunchbase is headquartered in San Francisco, USA.
} 


\section{Figure 5. AM Market "Outsiders" and "Champions" (difference in average} market shares in 2002-2004 and 2016-2018)

Champions

Outsiders

$$
\text { : }
$$

0

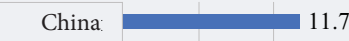

Germany 2.2

Taiwan 1.8

Korea $\quad 1.7$

Philippines 1.2
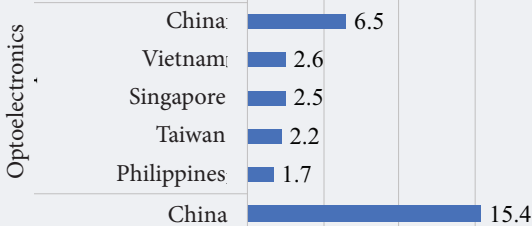

Taiwan $=1.9$

包

Mexico 1.8

Hong Kong 1.7

Vietnam 1.4

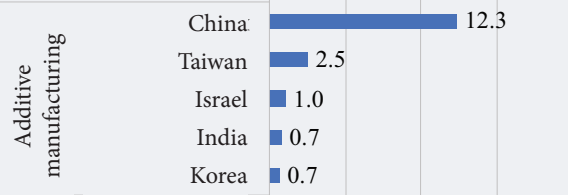

Ireland 9.7

Germany 2.0

Italy 1.3

UK -1.3

Korea 0.8

China: $\quad 3.6$

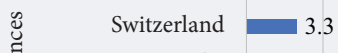

India $\quad 2.2$

Germany 1.5

Netherlands 1.3

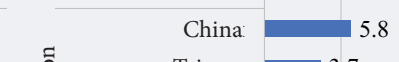

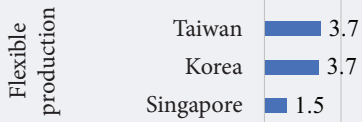

Malaysia $\quad 1.5$

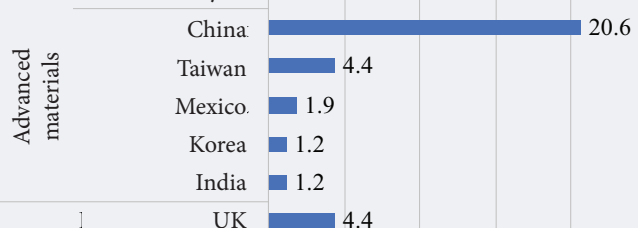

UK $\quad 4.4$

$\ddot{\mathscr{J}}) \quad$ Singapore $\quad 3.9$

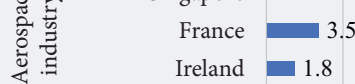

China: $\quad 1.7$

$\begin{array}{lll}\text { Russia } & 6.4\end{array}$

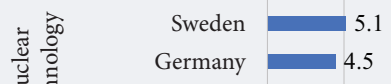

China $\quad 4.1$

Netherlands $\quad 3.6$

Russia $\quad 4.7$

\begin{tabular}{rrr} 
Korea & 3.4 \\
节 & Czech Republic & 1.8 \\
\hline है & South Africa & 1.8
\end{tabular}

Spain $\quad 1.2$

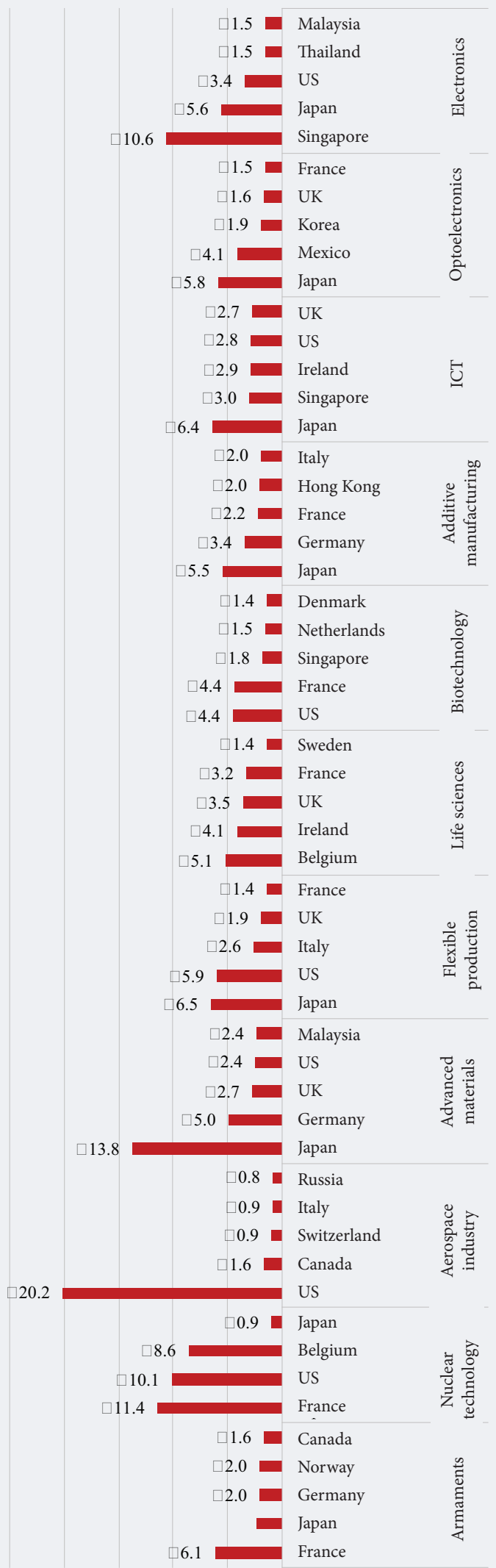

Sources: authors' calculations based on COMTRADE data and HS 2002 classification. 
Figure 6. Selected Countries' Positions in Terms of AM Product Import and Export Shares (truncated square): 2018

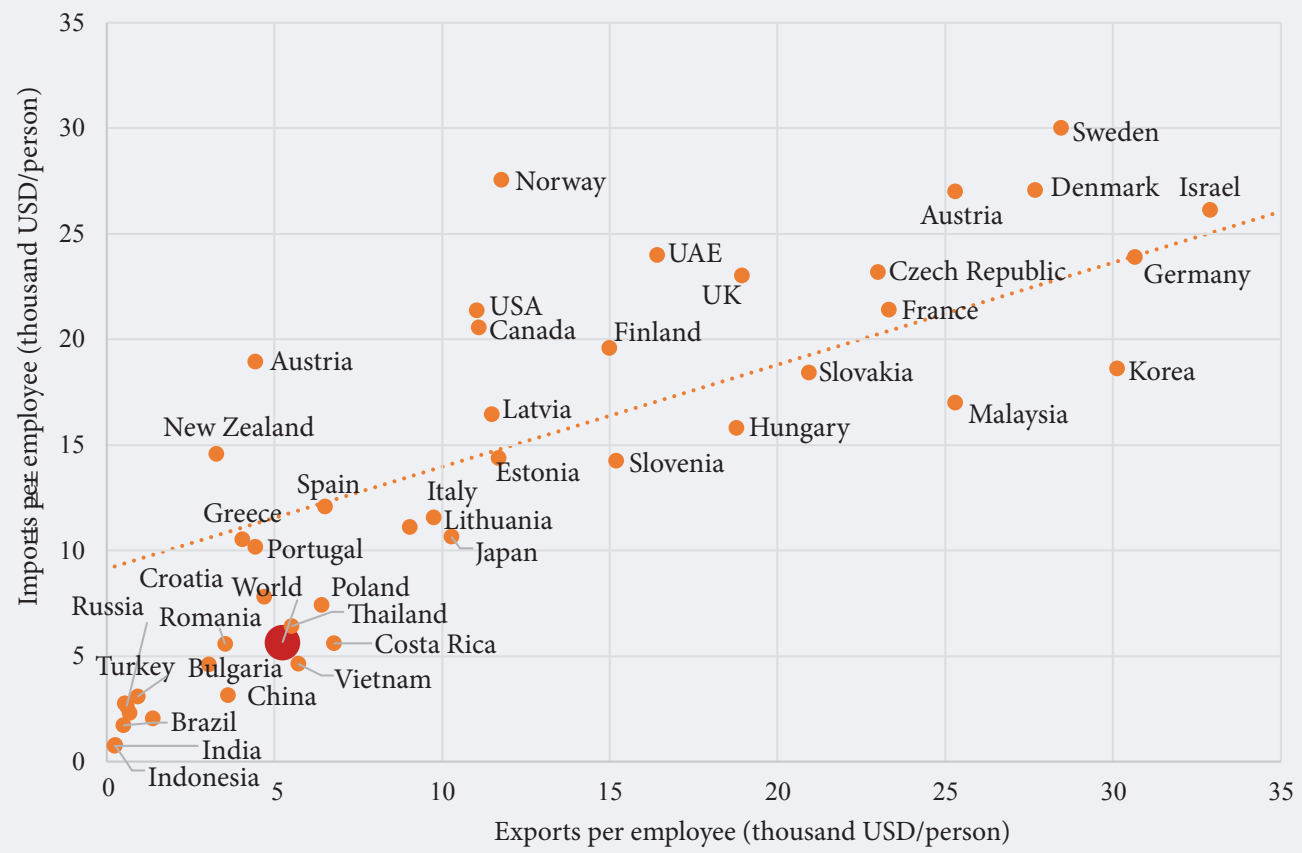

Sources: authors' calculations based on COMTRADE data and HS 2017 classification.

eral trade agreement (BTA) with the United States resulted in zero import costs for equipment.

Vietnam started to shape its innovation policy only in the 2000s. A number of specific "vertical" strategies were adopted, e.g., in mechanical engineering in 2006, along with laws on information technologies (2006) and high technologies (2008), and an act simplifying the registration of private enterprises. ${ }^{9}$ High-tech investors enjoy widespread support. Two major Samsung research centers operate in the country, where highly skilled local ICT engineers produce up to $10 \%$ of the company's global software output [Do, 2017]. Despite the advances in electronics, the prospects for technological innovation in the industry remain modest. Vietnam's experience in this field deepens the understanding of "classic" reasons for failures of attempts to promote growth by attracting foreign direct investment (shortage of skilled labor, etc.) [Paus, 2012; Hausmann, Rodrik, 2003; Hobday et al., 2001; Pham, Anh, 2020]. The lack of domestic firms' competences is largely the result of the government policy aimed at supporting only foreign manufacturers in particular by reducing corporate taxes. This has led to the increased technological backwardness of local businesses, which affected not only the electronics sector but also the supporting industries, whose insufficient develop- ment determined the strong import dependency of manufacturers.

\section{Ireland and Turkey: the development of bioindustry}

American pharmaceutical giants (Pfizer, Merck, Abbott, etc.) played a key role in the emergence of the Irish biotechnology market, having built their production facilities there. The key factors for choosing this location were easy access to the European market, simplified drug certification procedures, favorable tax regime, high-quality business environment, and the absence of a language barrier. ${ }^{10}$ The profit tax is one of the lowest in Europe, the total tax and contribution rate in 2019 was $26.1 \%$ (the EU average is $40 \%$ ) [World Bank, 2019]. Intellectual property tax depreciation, reimbursable research and development (R\&D) tax credits (25\%), and patent box deductions (6.25\%) are available for high-tech companies [PWC, 2020]. In addition to attracting the largest pharmaceutical companies, Ireland encourages R\&D and domestic biotech start-up creation. The Science Foundation Ireland established in 2003 allocates at least a quarter of its budget to finance biotech and related projects [Science Foundation Ireland, 2003, 2019]. In 2006, a special R\&D support program was launched with a budget of 2 million euros. The Medical and Engineering Technologies Centre was

\footnotetext{
9 In the year the law on new companies was passed, their number doubled in just four months compared to 1999. https://www.bc.edu/content/dam/files/ schools/law/lawreviews/journals/bciclr/25_1/03_TXT.htm, accessed on 14.03.2021.

${ }^{10} \mathrm{https} / /$ www.doingbusiness.org/en/data/exploreeconomies/ireland, accessed on 30.12.2020.
} 
Figure 8. Vietnam's Gross FDI Inflow, Net Exports, and Weighted Import Duties on Electronics and Equipment

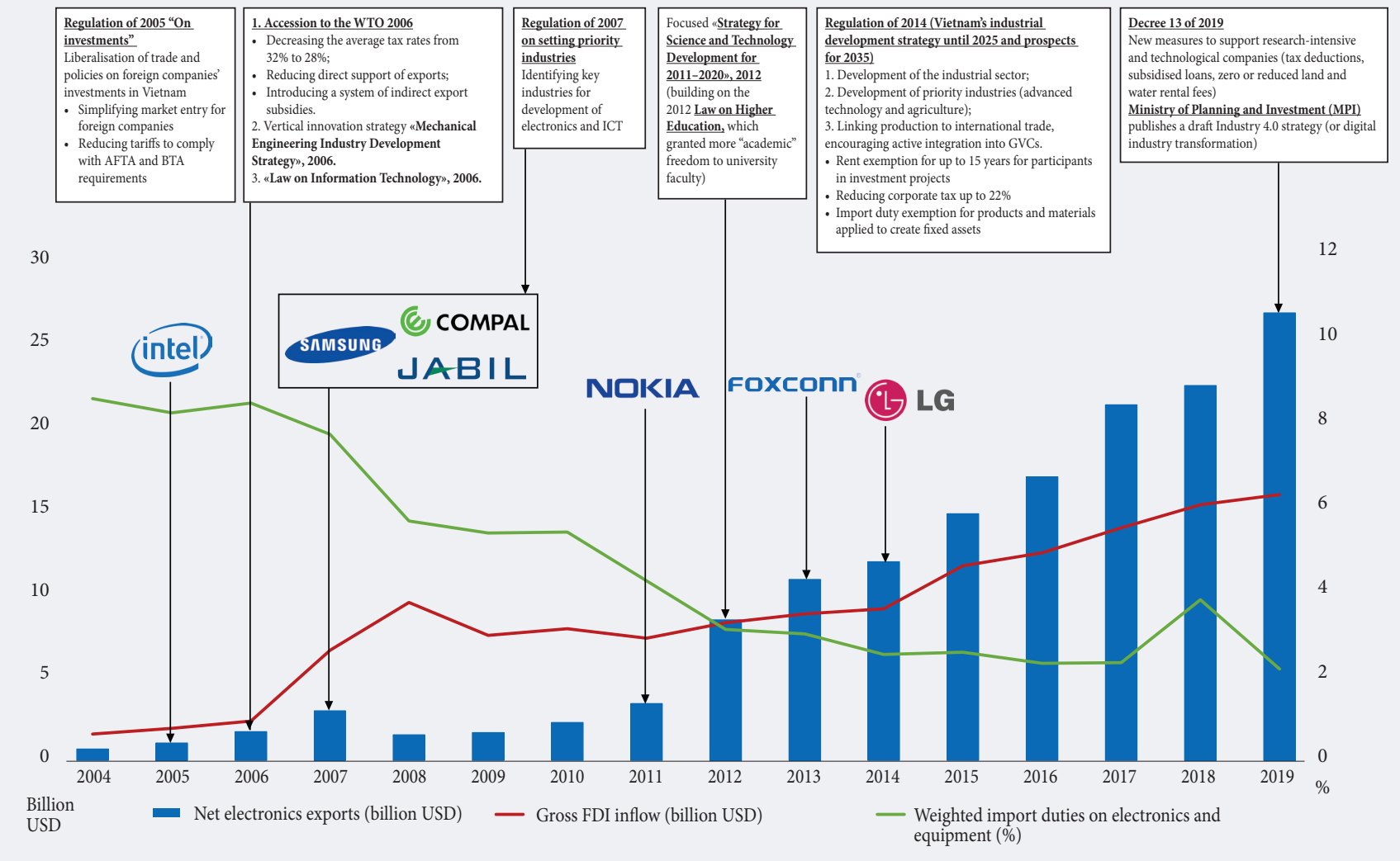

Note. Electronics exports include the following subgroups: optoelectronics, ICT, and electronics.

Sources: authors' calculations based on COMTRADE and WDI data and HS 2002 classification.

nology and other biotechnology groups [Severcan et al., 2000]. Several specialized research programs were successfully implemented. EU funding helped local research laboratories establish partnerships in Europe, the US, and other countries [Dundar, Akbarova, 2011]. The Biotechnology Strategy and Action Plan 2015-2018 in addition to promoting $\mathrm{R} \& \mathrm{D}$ were focused on supporting innovative companies. From 2016 to 2019, commercial enterprises' $\mathrm{R} \& \mathrm{D}$ expenditures increased significantly; in 2019, almost three quarters of total expenditures were made by small and medium-sized businesses. Over the same period, the number of companies selling biotech products grew from 140 to 211 .

Countries' biotechnology market growth models demonstrate a variety of approaches. In Ireland and Turkey, the government made the largest contribution to strengthening the sector's competitiveness. Ireland's approach seems to be more productive, but the actual industry development level depends on the political situation.

\section{South Korea: promoting science-industry partnership}

South Korea is a world leader in terms of R\&D expenditures. In Bloomberg's Innovation Index 2020, the country is second only to Germany, ${ }^{12}$ and in the Global Innovation Index, it ranks $11^{\text {th }}$ among 129 economies (Germany is $9^{\text {th }}$ ). ${ }^{13}$ South Korea has managed to closely integrate university science with the business environment, which helped the country achieve global leadership in terms of the share of researchers leaving the real sector to work in academia. In 2008, universities employed 70\% of the country's PhDs and industry $20 \%$, with the latter showing higher productivity [OECD, 2008].

In a short period of time South Korea has managed to bring several universities into the world's top 100, partly due to their deep integration into the business environment. Local universities lead in the share of co-publishing with the real sector. In the 2017 Times Higher Education ranking, ${ }^{14}$ Pohang University of Science and Technology (POSTECH) is first by this indicator and Sungkyunkwan Uni-

\footnotetext{
12 https://www.bloomberg.com/news/articles/2020-01-18/germany-breaks-korea-s-six-year-streak-as-most-innovative-nation, accessed on 14.03 .2021$.

${ }^{13} \mathrm{https} / / /$ www.wipo.int/publications/ru/details.jsp?id=4514, accessed on 14.03.2021.
} 
versity (SKKU) is eighth. These two universities' partnerships with chaebols on the South Korea Fair Trade Commission's list ${ }^{15}$ deserve more detailed consideration.

POSTECH was established by the Pohang Steel Company (POSCO) in line with the Caltech model, as a small campus focused on research and technological innovation [Cho, 2014]. One of the university's subsidiaries is the Research Institute of Science and Technology (RIST) which implements short-term projects to accelerate the testing of innovative iron and steel processing technologies and in areas such as engineering, advanced materials, management, and economics. Both sides benefit from using common infrastructure while maintaining autonomy from each other. ${ }^{16}$ Despite its small size, POSTECH has a developed partner network comprising 128 universities in 33 countries and is implementing a major joint project with the Max Planck Society.

SKKU, which has a long history as a traditional university, in the second half of the 20th century stagnated. In the late 1990s, Samsung affiliated its medical center with the university to conduct biomedical research, which brought the quality of medical services to a new level (Table 6). On this basis, a medical faculty was established at SKKU, along with the Centre for Semiconductor Research, the Computer Education Department, and the Graduate Business School. The university's development strategy largely serves Samsung's interests and is approved by the experts at the Samsung Economic Research Institute (SERI). SKKU currently has the status of corporate university and the company brand is present in the names of many of its divisions.

\section{Discussion of the Results and Policy Effects}

Over the past two decades the focus of industrial policy has shifted from providing selective protection, supporting import substitution, and betting on winners to promoting integration into value chains, digital transformation, supporting small and medium-sized businesses, and positioning the country in the new industrial revolution. Industrial policies of developed countries are becoming increasingly complex with long-term priorities flexibly adjusted to use the competitive potential to the maximum possible extent.

While the US, France, and Japan retain their leadership on the global AM markets, their shares in certain segments are gradually decreasing un- der pressure from new players undergoing a rapid structural transformation of their economies (Taiwan, South Korea, China). At the same time, the aforementioned leaders are switching to the emerging Industry 4.0 markets. The UK's positions in ICT and new materials have weakened, but the country expanded its presence on the biotechnology and aerospace markets. Germany has partially curtailed its activity in the new materials and additive manufacturing segments, but stepped it up in biotechnology, life sciences, and electronics.

Despite the global trends, Russian industrial policy remains vertical and hierarchical, focused on supporting large companies, while new players, including those in the growing AM sector, are facing problems with positioning. This is combined with lagging behind in terms of putting in place a sound regulation system for disruptive technology sectors. Development strategies for emerging ("sunrise") and declining ("sunset") industries must be separated. The emerging areas have high growth potential and scalability. However, some of these industries not only accelerate technological development but also require changes in the organization of traditional production, "cross-cutting" through a number of sectors (electronics, flexible production, new materials) [Wang, 1995].

Traditional and certain high-tech sectors alike are in decline (e.g., the textile and automotive industries). Falling into this group may be due to strategic decisions to reallocate resources and political support prompted by the lack of long-term prospects and the loss of a competitive edge.

Industry 4.0 markets are characterized by a high concentration of knowledge at universities combined with a high start-up activity, while Industry 3.0 ones tend to be dominated by large-scale production. The emerging AM markets imply the monopolization and rapid commercialization of new knowledge, while the features of "established" markets include in-depth specialization, consolidation of leading companies, and increased R\&D competition. As a result, the approaches to supporting different AM markets vary. In the case of emerging markets, priority is given to improving the business climate, stepping up innovation, and building new competencies. Many countries, regardless of their development level, analyze the emerging AM market trends and adapt their sectoral strategies to match the Industry 4.0 context [UNIDO, 2020; Dezhina, Ponomarev, 2014]. Successful countries' examples demonstrate that no universal recipes for achieving leadership exist. In each case, the unique

\footnotetext{
${ }_{14}$ https://www.timeshighereducation.com/news/south-korean-universities-lead-way-on-industry-collaboration, accessed on 14.03.2021.

${ }_{15}$ The list of the largest Korean chaebols includes: Samsung, Hyundai Motor Company, SK, LG, Lotte, POSCO, Hanwha, and GS. http://www.businesskorea. co.kr/news/articleView.html?idxno=45210, accessed on 14.03.2021.

${ }^{16}$ E.g., in 2017 an agreement was signed on the joint development of the artificial intelligence ecosystem at POSCO and training specialists in the area. https://newsroom.posco.com/en/posco-group-university-partners-postech-ai-specialists/, accessed on 14.03.2021.
} 
Table 6. Key features of university-business integration in Korea as illustrated by POSTECH+POSKO and SKKU+Samsung case studies

\begin{tabular}{|l|l|l|}
\hline Case & POSTECH + POSKO & SKKU + Samsung \\
\hline University rankings & POSTECH & SKKU \\
\hline THE World & 146 & 101 \\
\hline QS World & 77 & 88 \\
\hline ARWU World & $401-500$ & $201-300$ \\
\hline THE World (young) & 8 & - \\
\hline QS World (50 under 50) & 7 & - \\
\hline Size & $\begin{array}{l}3,087 \text { students, 2\% of them from abroad; 705 } \\
\text { professors }\end{array}$ & $\begin{array}{l}\text { 22,482 students, 18\% of them from abroad, 3,313 } \\
\text { professors }\end{array}$ \\
\hline Established & 1986 & 1996 \\
\hline Concept, year & $\begin{array}{l}\text { A small campus focused on research and } \\
\text { technological innovation }\end{array}$ & $\begin{array}{l}\text { Acquired by Samsung to build up Samsung Medical } \\
\text { SKKU's biomedical research expertise; SAMSUNG- }\end{array}$ \\
\hline Main driver of integration & POSTECH president & Ministry of Education \\
\hline $\begin{array}{l}\text { Decision-making autonomy } \\
\text { from corporate partner }\end{array}$ & High & Low \\
\hline Cooperation interests & $\begin{array}{l}\text { Mainly focused on the corporate partners' } \\
\text { objectives }\end{array}$ & Much wider \\
\hline $\begin{array}{l}\text { Corporate investments in } \\
\text { university }\end{array}$ & $\begin{array}{l}\text { Total POSCO investments >2 billion USD, } \\
\text { POSTECH budget = 320 million USD in 2020. }\end{array}$ & $\begin{array}{l}\text { Since 1997 Samsung annually spends on the SKKU } \\
50 \text {-100 million USD. }\end{array}$ \\
\hline $\begin{array}{l}\text { Sources: authors, based on [Stek, 2015; Cho, 2008, 2014; Innace, Dress, 1992] and THE, QS, ARWU, POSTECH data (http://www.postech.ac.kr/eng/ } \\
\text { about-postech/introduction-to-postech/postech-at-a-glance-2/\#). }\end{array}$ \\
\hline
\end{tabular}

national and industrial context should be considered. Some economies have made rapid progress by attracting foreign capital. However, such results are only possible in small countries, while their sustainability depends on the behavior of a few major international companies. For large economies, attracting foreign investment involves high costs. The absence of required specialized competencies hampers the inflow of foreign investments. The adoption of new technologies by "sunset" industries can become a driver of competitiveness and future growth. To achieve leadership on the AM markets, it is important not only to have sufficient human capital, but to also ensure its circulation between the academic and real sectors. Finally, in countries that have achieved success on the AM markets, the balance (net migration) is shifting in favor of the latter [Dayton, 2020]. University faculty can apply their competencies in production and expand the range of practically tested ideas, which is critically important for promoting emerging markets' growth.

AM market development strategies tend to be based on involving a network of stakeholders [UNIDO, 2020; Hausmann, Rodrik, 2003, 2018; Santiago, 2018] and adopting the "stakeholder capitalism" model [Schwab, Vanham, 2021; WEF, 2019]. Their success largely depends on decisionmakers' willingness and ability to forge a consistent vision [Lee, 2021], create opportunities for the early identification of trends [Paunov, Planes-Satorra, 2019], experiment, launch pilot projects, and select ideas and programs for scaling [Hausmann, Rodrik, 2003; Rodrik, 2018]. A top-down approach to co- ordinating technological change has demonstrated its effectiveness in catching-up countries such as Chile and Vietnam [UNIDO, 2020].

However, AMTs (at least some of them) are "crosscutting" in nature, blurring the traditional sector boundaries. Therefore, approaches to managing the transformation of production due to the emergence of new technologies need to be constantly adjusted and adapted. Alternative tools and frameworks are required to handle increasingly complex production systems characterized by multiple interdependencies between industries, companies, technologies, and subsystems [López-Gómez et al., 2017]. The "inclusiveness" and cross-cutting nature of new technologies require integrated government regulation and coordination [Lee, 2021]. As a result, establishing horizontal links between vertical strategies at the level of sectors, main actors, and stakeholders becomes relevant.

Sections "Methodology", "Structural features of global AM markets", "Positions of countries in AM markets", "Factors of country leadership in PP markets" were prepared within the framework of the grant of the President of the Russian Federation for state support of young Russian scientists "Assessment of Russia's participation in international trade in products related to the technologies of the Fourth Industrial Revolution, and its impact on improving Russia's position in global value chains "(agreement dated 20.04.2021 No. 07515-2021-318). The section "Cases of countries - new leaders in integration onto the AM markets" was prepared within the framework of the project "Effects of Russia's participation on global markets of advanced production and consequences for Russian structural policy", carried out as part of the HSE Program of Fundamental Research in 2021. 


\section{References}

Accenture (2014) The Flexible Manufacturer. Out-performing competition by changing the rules, Dublin: Accenture. https:// www.accenture.com/t20150523T035031__w__se-en/_acnmedia/Accenture/Conversion-Assets/DotCom/Documents/ Global/PDF/Dualpub3/Accenture-Flexible-Manufacturer-Out-Performing-Competition-Changing-Rules.pdf, accessed 20.04.2021

Ardito L., D’Adda D., Petruzzelli A.M. (2018) Mapping innovation dynamics in the Internet of Things domain: Evidence from patent analysis. Technological Forecasting and Social Change, 136, 317-330. https://doi.org/10.1016/j.techfore.2017.04.022

Balassa B. (1965) Trade liberalisation and "revealed" comparative advantage. The Manchester School, 33(2), 99-123. https:// doi.org/10.1111/j.1467-9957.1965.tb00050.x

Blanchet M., Rinn T., Dujin A., Geissler C. (2016) The Industrie 4.0 Transition Quantified: How the Fourth Industrial Revolution Is Reshuffling the Economic, Social and Industrial Model. Think Act - Beyond Mainstream, Munich: Roland Berger.

Castelo-Branco I., Cruz-Jesus F., Oliveira T. (2019) Assessing Industry 4.0 readiness in manufacturing: Evidence for the European Union. Computers in Industry, 107, 22-32. https://doi.org/10.1016/j.compind.2019.01.007

Cho M.H. (2008) Corporate Helix Model: The industry and triple helix networks. International Journal of Technology and Globalisation, 4(2), 103-120. https://doi.org/10.1504/IJTG.2008.018958

Cho M.H. (2014) Technological catch-up and the role of universities: South Korea's innovation-based growth explained through the Corporate Helix model. Triple Helix, 1(1), 1-20. https://doi.org/10.1186/s40604-014-0002-1

Dayton L. (2020) How South Korea made itself a global innovation leader. Nature, 581(7809), S54-S56). https://doi. org/10.1038/d41586-020-01466-7

Deloitte (2020a) 2021 Telecommunications industry outlook, London: Deloitte. https://www2.deloitte.com/content/dam/ Deloitte/us/Documents/technology-media-telecommunications/us-tmt-2021-outlook-for-the-us-tme-industry.pdf, accessed 30.12.2020.

Deloitte (2020b) Global trends on the pharmaceutical and biotechnology market, London: Deloitte. https://www2.deloitte. com/content/dam/Deloitte/ce/Documents/about-deloitte/ce_2020_global_life_sciences_outlook.pdf, accessed 30.12.2020.

Dezhina I., Ponomarev A. (2014) Advanced Manufacturing: New Emphasis in Industrial Development. Foresight-Russia, 8(2), 16-29 (in Russ.).

Do T.T.N. (2016) Assessing and Improving Rational Antimicrobial Use in Urban and Rural Health Care Facilities in Vietnam, Milton Keynes: Open University.

Dundar M., Akbarova Y. (2011) Current state of Biotechnology in Turkey. Current Opinion in Biotechnology, 22, S3-S6. https:// doi.org/10.1016/j.copbio.2011.05.509

EY (2020) Swiss Biotech Report, London:Ernst \&Young.https:/www.swissbiotech.org/wp-content/uploads/2020/05/20200421Swiss-Biotech-Report.pdf, accessed 30.12.2020.

Ferrantino M.J., Koopman R.B., Wang Z., Yinug F. (2010) The nature of US-China trade in advanced technology products. Comparative Economic Studies, 52(2), 207-224. https://doi.org/10.1057/ces.2010.6

Foster-McGregor N., Nomaler Ö., Verspagen B. (2019) Measuring the creation and adoption of new technologies using trade and patent data. Maastricht: UNU-MERIT. https://192.87.143.10/publications/wppdf/2019/wp2019-053.pdf, accessed 17.02.2021.

Fujii H., Managi S. (2018) Trends and priority shifts in artificial intelligence technology invention: A global patent analysis. Economic Analysis and Policy, 58, 60-69. https://doi.org/10.1016/j.eap.2017.12.006

Fulton M., Hon B. (2010) Managing advanced manufacturing technology (AMT) implementation in manufacturing SMEs. International Journal of Productivity and Performance Management, 59(4), 351-371. https://doi. org/10.1108/17410401011038900

Gasparatos A., Doll C.N., Esteban M., Ahmed A., Olang T.A. (2017) Renewable energy and biodiversity: Implications for transitioning to a Green Economy. Renewable and Sustainable Energy Reviews, 70, 161-184. https://doi.org/10.1016/j. rser.2016.08.030

Hallward-Driemeier M., Gaurav N. (2018) Trouble in the Making? The Future of Manufacturing-Led Development, Washington, DC: World Bank. https://doi.org/10.1596/978-1-4648-1174-6

Hausmann R., Rodrik D. (2003) Economic development as self-discovery. Journal of Development Economics, 72(2), 603-633. https://doi.org/10.1016/S0304-3878(03)00124-X

Hobday M., Cawson A., Kim S.R. (2001) Governance of technology in the electronics industries of East and South-East Asia. Technovation, 21(4), 209-226. https://doi.org/10.1016/S0166-4972(00)00038-9

Horváth D., Szabó R.Z. (2019) Driving forces and barriers of Industry 4.0: Do multinational and small and medium-sized companies have equal opportunities? Technological Forecasting and Social Change, 146, 119-132. https://doi.org/10.1016/j. techfore.2019.05.021

HSE (2018) Structural changes in the Russian economy and structural policy, Moscow: HSE (in Russ.).

IAEA (2020) Nuclear Technology Review 2020, Vienna: IAEA. https://www.iaea.org/sites/default/files/gc/gc64-inf2.pdf, accessed 30.12.2020.

Innace J.J., Dress A. (1992) Igniting Steel: Korea's POSCO Lights the Way, Tampa, FL: Global Village Press.

Kim G., Bae J. (2017) A novel approach to forecast promising technology through patent analysis. Technological Forecasting and Social Change, 117, 228-237. https://doi.org/10.1016/j.techfore.2016.11.023

Kim H.W., Qureshi Z. (eds.) (2020) Growth in a time of change: Global and country perspectives on a new agenda, Washington, D.C.: Brookings Institution Press. 
Kose I. (2017) Science and Technology Policies in Turkey. In: Researches on Science and Art in 21st Century Turkey (eds. H. Arapgirlioglu, A. Atik, R.L. Elliott, R. Turgeon), Ankara: Gece Kitapligi, pp. 1759-1774.

Lee K. (2021) Economics of technological leapfrogging, Vienna: UNIDO.

Lin J.Y. (2012) New Structural Economics: A Framework for Rethinking Development and Policy, Washington, D.C.: The World Bank.

Lineberger R. (2019) 2020 Global Aerospace and Defense Industry Outlook, London: Deloitte. https://www2.deloitte.com/ content/dam/Deloitte/global/Documents/Manufacturing/gx-global-outlook-ad-2020.pdf, accessed 30.12.2020.

López-Gómez C., Leal-Ayala D., Palladino M., O’Sullivan E. (2017) Emerging trends in global advanced manufacturing: Challenges, opportunities and policy responses, Vienna, Manchester: UNIDO, Cambridge University.

Marginson S. (2007) Global university rankings: Implications in general and for Australia. Journal of Higher Education Policy and Management, 29(2), 131-142. https://doi.org/10.1080/13600800701351660

Marginson S., van der Wende M. (2007) To rank or to be ranked: The impact of global rankings in higher education. Journal of Studies in International Education, 11(3-4), 306-329. https://doi.org/10.1177/1028315307303544

Mohan A., Roy A. (2017) A Strategic Investment Framework for Biotechnology Markets via Dynamic Asset Allocation and Class Diversification. https://arxiv.org/abs/1710.03267, accessed 12.06.2021.

Narain A. (2016) Electronics in South Asia, Washington, D.C.: World Bank. https://openknowledge.worldbank.org/bitstream/ handle/10986/25118/108827-WP-P146865-PUBLIC-electronics.pdf?sequence=1\&isAllowed=y, accessed 14.04. 2021.

Naudé W., Surdej A., Cameron M. (2019) Ready for Industry 4.0? The Case of Central and Eastern Europe. In: Industry 4.0 and Engineering for a Sustainable Future (eds. M. Dastbaz, P. Cochrane), pp. 153-175. Heidelberg, Dordrecht, London, New York: Springer. https://doi.org/10.1007/978-3-030-12953-8_10

Ngoc T.T.B., Binh D.T. (2019) Vietnam's Electronics Industry: The Rise and Problems of Further Development. Humanities \& Social Sciences Reviews, 7(4), 1-12. https://doi.org/10.18510/hssr.2019.741

OECD (2008) OECD Review of Korea's Innovation Policy, Paris: OECD. https://read.oecd-ilibrary.org/science-and-technology/ oecd-reviews-of-innovation-policy-korea-2009_9789264067233-en\#page1, accessed 30.12.2020.

Osborne-Kinch J., Coates D., Nolan L. (2017) The aircraft leasing industry in Ireland: Cross border flows and statistical treatment. Central Bank of Ireland Quarterly Bulletin Articles, 1, 58-69. https://www.centralbank.ie/docs/default-source/ publications/quarterly-bulletins/quarterly-bulletin-signed-articles/the-aircraft-leasing-industry-in-ireland.pdf?sfvrsn=6, accessed 24.02.2021.

Özdamar T.H. (2009) Biotechnology in Turkey: An Overview. Biotechnology Journal: Healthcare Nutrition Technology, 4(7), 981-991. https://doi.org/10.1002/biot.200900145

Paunov C., Planes-Satorra S. (2019) How are digital technologies changing innovation? Evidence from agriculture, the automotive industry and retail, Paris: OECD. https://doi.org/10.1787/23074957

Paus E. (2012) Confronting the middle income trap: insights from small latecomers. Studies in Comparative International Development, 47(2), 115-138. https://doi.org/10.1007/s12116-012-9110-y

Pham H.S.T., Nguyen A.N., Johnston A. (2020) Economic policies and technological development of Vietnam's electronics industry. Journal of the Asia Pacific Economy, 1-22. https://doi.org/10.1080/13547860.2020.1809055

PWC (2020) Investing in Ireland, Dublin: PWC. https://www.pwc.ie/publications/2020/fdi-investing-in-ireland-issue-42.pdf, accessed 30.12. 2020.

Reischauer G. (2018) Industry 4.0 as policy-driven discourse to institutionalize innovation systems in manufacturing. Technological Forecasting and Social Change, 132, 26-33. https://doi.org/10.1016/j.techfore.2018.02.012

Rodrik D. (2018) New Technologies, Global Value Chains, and Developing Economies (NBER Working Paper 25164). Cambridge, MA: National Bureau of Economic Research. https://doi.org/10.3386/w25164

Santiago F. (2018) You say you want a revolution: Strategic approaches to Industry 4.0 in middle-income countries, Vienna: UNIDO.

Schwab K., Davis N. (2018) Shaping the future of the fourth industrial revolution, New York: Currency.

Schwab K., Vanham P. (2021) Stakeholder capitalism: A global economy that works for progress, people and planet, New York: John Wiley \& Sons, Inc.

Science Foundation Ireland (2003) Annual report and accounts 2003, Dublin: Science Foundation Ireland. https://www.sfi.ie/ research-news/publications/annual-reports/SFI-Annual-Report-2003.pdf, accessed 30.12. 2020.

Science Foundation Ireland (2019) Annual report and accounts 2019, Dublin: Science Foundation Ireland. https://www.sfi.ie/ research-news/publications/annual-reports/SFI-2019-Annual-Report-(English).pdf, accessed 30.12. 2020.

Severcan F., Ozan A., Haris P.I. (2000) Development of biotechnology education in Turkey. Biochemical Education, 28(1), 36-38. https://doi.org/10.1111/j.1539-3429.2000.tb00011.x

Shipp S.S., Gupta N., Lal B., Scott J.A., Weber C.L., Finnin M.S., Thomas S. (2012) Emerging global trends in advanced manufacturing, Alexandria VA: Institute For Defense Analyses.

Simachev Y., Kuzyk M., Pogrebnyak E. (2018) Federal Industrial Policy: Basic Models and Russian Practice. The Journal of the New Economic Association, 3 (39), 146-154. DOI: 10.31737/2221-2264-2018-39-3-8 (in Russ.).

Simachev Y.V., Fedyunina A., Kuzyk M.G. (2020) Industrial revolution 4.0 in the BRICS countries: What are the challenges for industrial policy? BRICS Journal of Economics, 1(3), 4-22.

Stek P. (2015) The strategic alliance between Sungkyunkwan University and the Samsung Group: South Korean exceptionalism or new global model? Helice, 4. https://www.triplehelixassociation.org/helice/volume-4-2015/helice-issue-12/the-strategicalliance-between-sungkyunkwan-university-and-the-samsung-group-south-korean-exceptionalism-or-new-globalmodel, accessed 15.12.2020. 
STPI (2010) White Papers on Advanced Manufacturing Questions. Draft Working Papers Version 040510, Washington, DC: Science and Technology Policy Institute. https://www.nist.gov/system/files/documents/2017/05/09/advanced-manufpapers.pdf, accessed 06. 04.2020.

Tansan B., Gökbulut A., Targotay Ç., Tevfik E. (2016) Industry 4.0 in Turkey as an Imperative for Global Competitiveness: An Emerging Market Perspective, Istanbul: TÜsİAD.

Tofail S.A., Koumoulos E.P., Bandyopadhyay A., Bose S., O’Donoghue L., Charitidis C. (2018) Additive manufacturing: Scientific and technological challenges, market uptake and opportunities. Materials Today, 21(1), 22-37. https://doi. org/10.1016/j.mattod.2017.07.001

Tuesta E.F., Garcia-Zorita C., Ayllon R.R., Sanz-Casado E. (2019) Does a Country/Region's Economic Status Affect Its Universities' Presence in International Rankings? Journal of Data and Information Science, 4(2), 56-78. https://doi. org/10.2478/jdis-2019-0009

UNCTAD (2019) Contribution of Turkey to the Commission on Science and Technology for Development (CSTD) 2018-19 Priority Theme on 'The Impact of Rapid Technological Change on Sustainable Development', Vienna: UNCTAD. https://unctad. org/system/files/non-official-document/CSTD_2019_IPanel_T1_RapidTech_con11_Turkey_en.pdf, accessed 27.04.2021.

UNIDO (2020) Competitive Industrial Performance Index 2020: Country Profiles, Vienna: UNIDO. https://stat. unido.org/content/publications/competitive-industrial-performance-index-2020\%253a-country-profiles? $\mathrm{ga}=2.161772281 .455182122 .1612350573-1676216167.1612350573$, accessed 30.12.2020.

UNODC (2019) The legal market in firearms, Vienna: UNODC. https://www.unodc.org/documents/e4j/Module_03_-_Legal_ Market_in_Firearms_FINAL.pdf, accessed 30.12.2020.

van Wilgenburg B., van Wilgenburg K., Paisner K., van Deventer S., Rooswinkel R.W. (2019) Mapping the European startup landscape. Nature Biotechnology, 37(4), 345-349. https://doi.org/10.1038/s41587-019-0076-4

Wang V.W.C. (1995) Developing the information industry in Taiwan: Entrepreneurial state, guerrilla capitalists, and accommodative technologists. Pacific Affairs, 68(4), 551-576. https://doi.org/10.2307/2761276

WEF (2019) Global Technology Governance A Multistakeholder Approach, Geneva: WEF. http://www3.weforum.org/docs/ WEF_Global_Technology_Governance.pdf, accessed 30.12.2020.

World Bank (2016) World Development Report 2016: Digital Dividends, Washington, D.C.: World Bank.

World Bank (2019) World Development Report 2020: Trading for Development in the Age of Global Value Chains, Washington, D.C.: World Bank. 